\title{
Melting Point and Transformation of Pure Chromium
}

\author{
by D. S. Bloom, J. W. Putman, and N. J. Grant
}

EVERAL recent determinations of the melting
point of pure chromium have been reported
which give values of $1845^{\circ} \mathrm{C}^{1} 1892^{\circ} \mathrm{C},{ }^{2} 1930^{\circ} \mathrm{C}^{8}$
$1860^{\circ} \mathrm{C},{ }^{4}$ and $1890^{\circ} \mathrm{C} .^{5}$ Because of this wide spread
of values, it appeared desirable to make one addi-
tional attempt to obtain a more accurate, reliable
figure. Bloom and Grant recently reported a phase
transformation in chromium; it was desired to check
this, too, in the course of checking the melting point.
To accomplish this, a much higher purity chro-
mium was required. Electrolytic chromium con-
taining about 0.5 pct O was crushed to a finer size
and was then annealed in highly purified, dried
hydrogen at $1375^{\circ} \mathrm{C}$ for 100 hr. This treatment
produced chromium with about 0.008 pct $\mathrm{O}$, 0.002
pct $\mathrm{N}$, and negligible carbon. The balance of the
impurities was 0.3 pct Fe, 0.03 pct Si, 0.004 pct $\mathrm{S}$,
and less than 0.001 pct Mo. This chromium was

Table I. Melting and Transformation Temperature Data

\begin{tabular}{|c|c|c|c|c|}
\hline \multirow[b]{2}{*}{$\begin{array}{l}\text { Thermo- } \\
\text { couple }\end{array}$} & \multicolumn{2}{|c|}{ Melting Point } & \multicolumn{2}{|c|}{$\alpha \underset{\text { Transformation }}{(\text { b.c.c.) }} \leftrightarrows \beta$ (f.c.c.) } \\
\hline & Emt $(m v)$ & $\begin{array}{l}\text { Tempera- } \\
\text { ture, oC }\end{array}$ & Emf $(\mathbf{m v})$ & $\begin{array}{c}\text { Tempera- } \\
\text { ture, } \circ \mathbf{C}\end{array}$ \\
\hline No. 1 & $\begin{array}{l}4.65(\mathrm{c}) * \\
4.77(\mathrm{~h}) \dagger \\
4.70(\mathrm{c}) \\
4.80(\mathrm{~h})\end{array}$ & $\begin{array}{l}1886 \\
1903 \\
1894 \\
1908\end{array}$ & $\begin{array}{l}4.38 \\
4.15 \\
4.30\end{array}$ & $\begin{array}{l}1848 \\
1815 \\
1836\end{array}$ \\
\hline No. 2 & $\begin{array}{l}4.77(\mathrm{c}) \\
4.83(\mathrm{~h}) \\
4.80(\mathrm{c}) \\
4.82(\mathrm{~h})\end{array}$ & $\begin{array}{l}1903 \\
1912 \\
1908 \\
1911\end{array}$ & $\begin{array}{l}4.43 \\
4.38\end{array}$ & $\begin{array}{l}1855 \\
1848\end{array}$ \\
\hline Average & 4.77 & 1903 & 4.33 & 1840 \\
\hline
\end{tabular}

* (c) $=$ cooling.

$\dagger($ (c) $=$ cooling.
$\dagger($ h) $=$ heating.

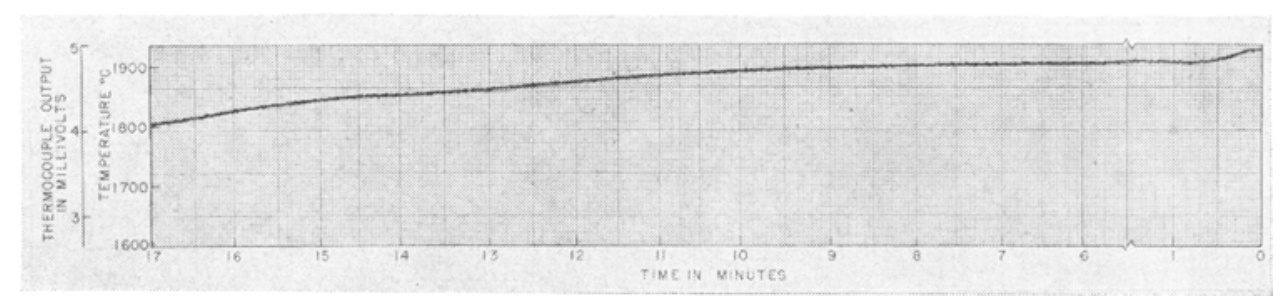

Fig. 1-Cooling curve of chromium indicating solidification at $4.80 \mathrm{mv}\left(1908^{\circ} \mathrm{C}\right)$ and transformation at about $4.43 \mathrm{mv}\left(1855^{\circ} \mathrm{C}\right)$. Note deletion of $4 \mathrm{~min}$ of the curve during solidification period.

melted in a stabilized zirconia crucible under prepurified argon, using induction heating. Temperature measurements were made with annealed wolfram-molybdenum thermocouples and a Leeds and Northrup Speedomax Recording Potentiometer. The thermocouples were annealed for $1 \mathrm{~min}$ in hydrogen at a temperature of about $2400^{\circ} \mathrm{C}$.

Each leg of the thermocouple was immersed in an ice-water mixture using mechanical connectors to the lead wires. The thermocouple tip was immersed in the molten chromium in a zirconia protection tube which introduces an error of about $3^{\circ} \mathrm{C}$ as a temperature drop through the walls of the tube. The weight of chromium was about $183 \mathrm{~g}$. The dimensions of the melt in the crucible were about 1.25 in. diam $\times 2$ in. high. The tip of the thermocouple was held about $1 / 2$ in. from the bottom of the crucible. Two new thermocouples were used with the above set-up giving the results shown in Table I.

Since this chromium is purer than that used by Greenaway, Johnstone and McQuillan, ${ }^{1}$ by Carlile

D. S. BLOOM, Student Associate AIME, and J. W. PUTMAN are Research Assistants, and N. J. GRANT, Member AIME, is Associate Professor, Dept. of Metallurgy, Massachusetts Institute of Technology, Cambridge, Mass.

TN 113E. Manuscript, Feb. 6, 1952. et al., ${ }^{4}$ and other investigators, ${ }^{2,3}$ it is believed to be the more accurate. Thermocouple aging effects which are believed responsible for the high value of $1930^{\circ} \mathrm{C}^{3}$ were avoided in this work. This value of $1903^{\circ} \mathrm{C}$ is correct to about $\pm 10^{\circ} \mathrm{C}$.

The right hand column lists the temperature of the $\alpha \rightarrow \beta$ transformation on heating and the $\beta \rightarrow \alpha$ on cooling. ${ }^{3}$ A sample curve is shown in Fig. 1 . The value so determined is $1840^{\circ} \mathrm{C} \pm 15^{\circ} \mathrm{C}$. Fig. 1 gives adequate evidence that there is a transformation in chromium at high temperatures. ${ }^{3}$

\section{References}

${ }^{1}$ H. T. Greenaway, S. T. M. Johnstone, and M. K. McQuillan: High Temperature Thermal Analysis Using the Tungsten-Molybdenum Thermocouple. Journal Inst. Metals (November 1951) 19, p. 109.

${ }^{2}$ J. W. Putman, R. D. Potter, and N. J. Grant: The Ternary System Chromium-Molybdenum-Iron. Trans. A.S.M. (1951) 43, p. 824.

${ }^{3}$ D. S. Bloom and N. J. Grant: Chromium-Nickel Phase Diagram. Trans. AIME (1951) 191, p. 1009; Journal of Metals (November 1951).

${ }^{4}$ S. J. Carlile, J. W. Christian, and W. Hume-Rothery: The Equilibrium Diagram of the System ChromiumManganese. Journal Inst. Metals (1949) 76, p. 169.

${ }^{5} \mathrm{G}$. Grube and $\mathrm{R}$. Knabe: Ztsch. Elektrochemie (1936) 42, p. 793. 